\title{
SPATIAL DISTRIBUTION OF MACROBENTHIC FAUNA ON THREE SANDY BEACHES FROM NORTHERN RIO GRANDE DO SUL, SOUTHERN BRAZIL
}

\author{
Frederico Monteiro Neves* \& Carlos Emílio Bemvenuti \\ Fundação Universidade Federal do Rio Grande, FURG \\ Departamento de Oceanografia \\ (Caixa Postal 474, 96201-900, Rio Grande, RS, Brasil) \\ *E-mail: fmonteironeves@yahoo.com.br
}

\begin{abstract}
A B S T R A C T
The spatial distribution of benthic macrofauna on the beaches of Tramandaí, Jardim do Éden and Harmonia, was investigated over five consecutive days in April, 2003. The distribution pattern was also analyzed along with environmental parameters. Three transects were set on each beach, $50 \mathrm{~m}$ apart, with four sample stations set along each transect. On every station, three samples of benthic macrofauna were taken daily, with a core sampler with $20 \mathrm{~cm}$ diameter. In the midlittoral zone, the polychaete Euzonus furciferus and the isopod Excirolana armata dominated. In the swash zone, tidal migrators, Emerita brasiliensis, Donax hanlevanus and Mesodesma mactroides, were the most abundant species and, on some days, the polychaete Scolelepis gaucha. In the lower zones of the beaches, D. hanleyanus, M. mactroides and the amphipod Puelche orensani dominated. This zonation pattern was found for all three studied beaches, based on the average density of each species, over the five days period. Horizontal variation in the fauna was not found, either inter or intra the studied beaches, possibly due to little variability in slope and homogeneity of sediment grain size presented in the three beaches.
\end{abstract}

\section{R ESUMO}

A distribuição espacial da macrofauna bentônica nas praias de Tramandá, Jardim do Éden e Harmonia foi investigada durante cinco dias consecutivos no mês de abril de 2003. Foi analisado também o padrão de distribuição da fauna em relação aos parâmetros ambientais. Foram demarcadas três transversais distantes $50 \mathrm{~m}$ uma da outra em cada praia e em cada transversal foram inseridas 4 estações, nas quais foram tomadas diariamente 3 amostras da macrofauna bentônica com um corer de $20 \mathrm{~cm}$ de diâmetro. No mesolitoral dominaram o poliqueta Euzonus furciferus e o isópode Excirolana armata. Na zona de varrido, os migradores mareais Emerita brasiliensis, Donax hanleyanus e Mesodesma mactroides foram os mais abundantes. Nas zonas inferiores das praias, dominaram $D$. hanleyanus, M. mactroides e o anfípode Puelche orensanzi. Este padrão de zonação foi encontrado para as três praias com base na média da densidade de cada espécie nos cinco dias estudados. Não foi encontrada variação na distribuição horizontal da fauna dentro e entre praias, provavelmente, devido a pouca variabilidade da declividade e a homogeneidade do tamanho do grão de sedimento que apresentaram as três praias.

Key words: Benthic macrofauna; Spatial and temporal distribution; Sandy beaches; Rio Grande do Sul littoral.

Palavras chave: Macrofauna bentônica; Distribuição espacial e temporal; Praias arenosas; Litoral do Rio Grande do Sul.

\section{INTRODUCTION}

Benthic macrofauna of sandy beaches may present a patchy distribution variable in response to hydrodynamic and migratory factors (Dexter, 1992; McLachlan et al., 1993; McLachlan \& Jaramillo, 1995; McLachlan, 1990, 1996; Veloso \& Cardoso, 2001). Patchy distribution is the typical result of passive selection, mainly performed by wave action and food concentration. The patch size may range from $10 \mathrm{~m}$ in reflective beaches up to $100 \mathrm{~m}$ in high energy dissipative beaches (McLachlan \& Hesp, 1984).
Many authors have proposed macrofauna zonation schemes for sandy beaches. Among them, Dahl (1952) has divided the beach region into three zones, based on the distribution of crustaceans, forming a "sub-terrestrial fringe", characterized by the presence of crabs from the genera Ocypode (tropical and subtropical regions) and talitrid amphipods (temperate and subpolar regions), a "midlittoral" zone, inhabited by cirolanid isopods, and a "sublittoral fringe" including hippids crabs, in tropical regions and haustorid amphipods and others, in temperate regions. Based on other beach characteristics, Salvat (1964) proposed a zonation scheme taking into account the beach physical features. This author has defined: (1) 
dry sand zone, reached by ocean spray and highest tide; (2) retention zone, reached by all tides; (3) resurgence zone, set; (4) saturation zone, permanently saturated by water.

In a revising work on the status of knowledge about sandy beach macrofauna zonation pattern, McLachlan \& Jaramillo (1995) concluded that macrofauna distribution across shore assumes the form of three distinct and universal zones based on the distribution of characteristic taxa, being divided into supralittoral, littoral and sublittoral zones.

Not much is known of zonation patterns of benthic macrofauna in sandy beaches from southern Brazil, where most works are related to auto-ecology of macrozoobenthic populations, distribution, population dynamics and secondary production of benthic fauna (Gianuca, 1983, 1985, 1987; Borzone \& Gianuca, 1990; Borzone, 1991; Souza \& Gianuca, 1995; Borzone et al., 1996; Borzone \& Souza, 1997). Among them, Gianuca $(1983,1985)$ observed highest biomass and production of benthic invertebrates in the midlittoral zone of sandy beaches in the south of Rio Grande do Sul. The same author, based on qualitative information, verified a vertical distribution of fauna dependent on tidal flood in beaches with intermediate and dissipative characteristics (Gianuca, 1987). Northwards, in a beach of Paraná state, Borzone \& Souza (1997) found a macrofauna zonation pattern adjusted to the scheme proposed by Salvat (1964), with high similarities between the saturation and breaker zones.

Besides the necessity to characterize the benthic macrofauna spatial distribution based on quantitative sampling and replication, it is also urgent to build up knowledge on these environments, considering the rise of anthropogenic influences on sandy beaches from northern Rio Grande do Sul. Therefore, the aim of this work was to characterize and compare the vertical and horizontal distribution patterns of benthic macrofauna on three beaches in the north shore of Rio Grande do Sul State.

\section{Material and Methods}

This work was conducted in the beaches of Tramandaí, Jardim do Éden and Harmonia, all on north shore of Rio Grande do Sul state (Fig. 1). The places for sampling were set $10 \mathrm{~km}$ apart from each other, with Tramandaí as the central point. This beach has a width of about $100 \mathrm{~m}$ from the dune ridge to the upper limit of the swash zone. The dune strip is narrow (about $11 \mathrm{~m}$ ), confined between the road and the parking area for cars and pedestrians. Jardim do Éden beach, south of Tramandaí, has a wide foredune system, with a width of about $50 \mathrm{~m}$ between the dunes and the upper limit of the swash zone. Harmonia beach, north of Tramandaí, has a narrow strip of dunes $(15 \mathrm{~m})$, restricted by the presence of beachside houses. The distance between the dunes and the upper limit of the swash zone is about $40 \mathrm{~m}$.

Benthic macrofauna was sampled daily from April 7 to 11th, 2003, at low tide range, near the fishing platform of Tramandaí beach $\left(30^{\circ} 00^{\prime} 221 \mathrm{~S} \mathrm{e}\right.$ $\left.050^{\circ} 07^{\prime} 821 \mathrm{~W}\right)$, at $10 \mathrm{~km}$ northwards in Harmonia beach $\left(29^{\circ} 54^{\prime} 857 \mathrm{~S}\right.$ e $\left.050^{\circ} 05^{\prime} 421 \mathrm{~W}\right)$ and at $10 \mathrm{~km}$ southwards, in the Jardim do Éden beach $\left(30^{\circ} 05^{\prime} 800 \mathrm{~S}\right.$ e $050^{\circ} 10^{\prime} 238 \mathrm{~W}$ ).

In order to characterize the zonation of benthic macroinvertebrates, three transects were set on each beach, from the intertidal zone down to $1.0 \mathrm{~m}$ depth seawards, along which four stations were placed for quantitative sampling of macrozoobenthos. Transects were placed $50 \mathrm{~m}$ away from each other within each beach (Fig. 2). On the supralittoral zone, the occurence of crabs Ocypode quadrata and their burrows was verified. 2

On each station, three samples were taken, a total of 36 samples daily for each beach. During the five days of studies, a total sum of 540 samples of benthic macrofauna was taken. Station \#1 was placed $8 \mathrm{~m}$ above the swash zone upper limit at low tide, according to measurements made daily at the moment of sampling. Station \#2 was always placed in the swash zone. Station \#3 was placed at the limit of the swash zone and the beginning of the inner breaker zone, and station \# 4 at $1 \mathrm{~m}$ depth.

Distance between the four stations was obtained using a measuring tape. After the distance between the top and bottom stations (\#1 and \#4) was obtained, it was equally subdivided for intermediate stations ( \#2 and \#3).

Owing to the fact that stations were fixed daily according to the upper limit of the swash zone, every day sampling was possible at each of the proposed zones, regardless of the water line shifting. So it was possible to verify the faunal distribution along the days, from $8 \mathrm{~m}$ above the swash zone upper limit down to 1 meter depth in the inner breaker zone. With the proposed sampling design it was possible to verify, besides the vertical variation, the horizontal variation of the faunistic zones within beaches (between transects) and between beaches, as proposed by James \& Fairweather (1996).

Samples were taken using a PVC extractor tube with $20 \mathrm{~cm}$ diameter $\left(0.031 \mathrm{~m}^{2}\right)$, pushed $20 \mathrm{~cm}$ deep into the sediment bed. The biological samples were sieved in the field, using a nylon mesh of 0.5 $\mathrm{mm}$. The material retained was fixed in $10 \%$ formalin, packed into plastic bags, properly identified and taken to the laboratory for later processing. The organisms were identified to the lowest possible taxon, using a stereoscopic microscope, and quantified. Density was extrapolated to individuals per square meter. 


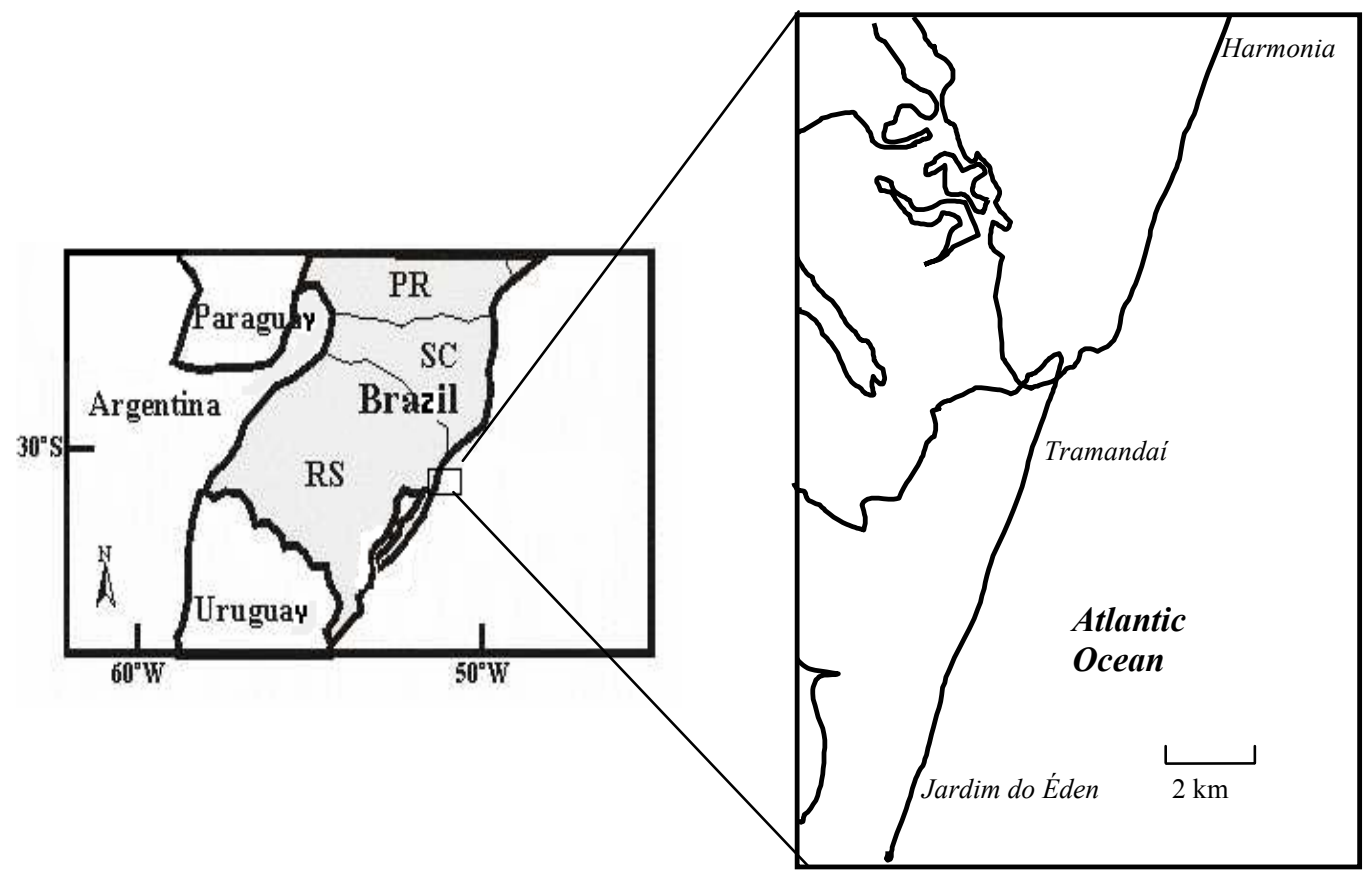

Fig. 1. Study site. Jardim do Éden and Harmonia beaches are $10 \mathrm{~km}$ distant from Tramandaí beach.

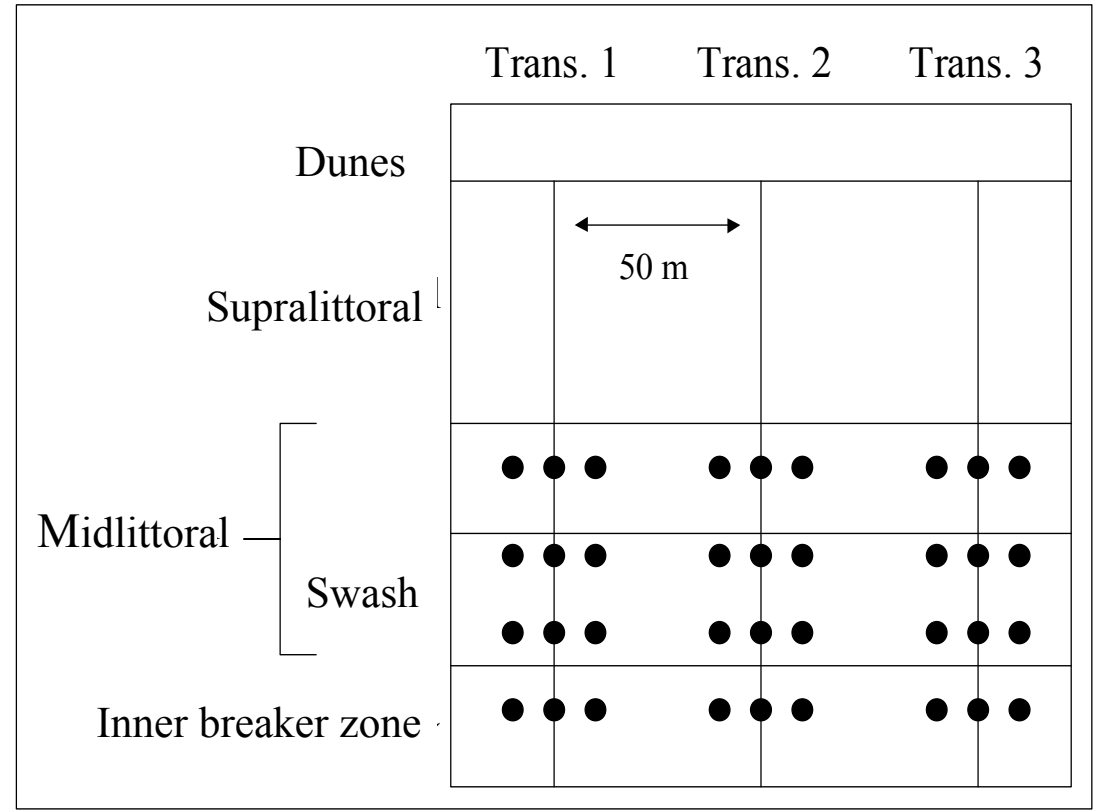

Fig. 2. Sampling scheme showing the position of transversals and stations on the three studied beaches. Trans. - Transversal; black circle - sample. 
Topographical profiles were drawn daily, following the same line used for biological sampling according to the method proposed by Birkemeier (1985). The points were chosen considering the beach geomorphologic features, from the base of the frontal dunes to the inner breaker zone.

Beach morphodynamic stage was described using Dean's $\Omega\left[\Omega=\mathrm{H}_{\mathrm{b}} /\left(\mathrm{T} \times \mathrm{W}_{\mathrm{s}}\right)\right]$ parameter, according to Wright \& Short (1984). Wind velocity (anemometer), wave period and height (visual observation) and water temperature (thermometer) and salinity (refractometer) data were collected together with biological sampling.

As many as 36 samples of sediment were collected (in the penultimate day) with a PVC tube (20 $\mathrm{cm}$ diameter) at each sampling station, in every beach, for grain size analysis. Sand, silt and clay proportions were determined with sieves $(>0,062 \mathrm{~mm}$ diameter $)$ and pipettes $(<0,062 \mathrm{~mm}$ diameter $)$, according to Suguio (1973).

Analyses were made using the software PRIMER v5 (Plymouth Routines In Multi Ecological Research), with the original spreadsheet of density (ind $/ 0.031 \mathrm{~m}^{2}$ ) of species per sample. First of all, a spreadsheet of similarities between paired samples $(\mathrm{Q}$ mode) was extracted for each beach, with square root transformation according to Bray-Curtis index (Raffaelli et al., 1991).

The next step was testing the hypothesis, through similarity analysis (ANOSIM-one way), of no differences between transects within each beach. The similarity analyses were performed using the general data from each beach and also using the set of data from the three beaches together, using stations as factors. For the latter analysis (set of data from the three beaches together), the mean was worked out for samples from each station (3 samples), within each transect. Groups were considered different with significance level $\mathrm{p}<0,05$ and $\mathrm{R}>0,5$.

From the similarity spreadsheet a non-metric multi-dimensional scaling analysis (MDS) was done for each beach and for the set of data from the three beaches. To verify the contribution of each species to the differences between two groups, a percentage analysis of similarity was performed (SIMPER).

\section{Results}

This work was carried out between two storm surges. A day before the beginning of sampling, the average wind velocity in Tramandaí was $9 \mathrm{~m} / \mathrm{s} \mathrm{SW}$, with wave height of $3 \mathrm{~m}$ and $14 \mathrm{~s}$ wave period. For the three beaches, the first sampling day was carried out with winds of about $4 \mathrm{~m} / \mathrm{s} \mathrm{SW}$, ranging up to the average of $9.5 \mathrm{~m} / \mathrm{s} \mathrm{W}$ in the last day. Wave period was $14 \mathrm{~s}$ during the first day, reaching $9 \mathrm{~s}$ in the last day. Wave height ranged from $2.5 \mathrm{~m}$ in the first day to 1.5 $\mathrm{m}$ in the fourth day and $1.75 \mathrm{~m}$ in the last day. Water temperature ranged from $19^{\circ} \mathrm{C}$ to $23^{\circ} \mathrm{C}$ and salinity from 32 to 34 , during the study period.

On days 1,2 and 5, the presence of diatom Asterionellopsis glacialis blooms was verified visually in all the three studied beaches from the breaker zone to the swash zone.

Tramandaí, Harmonia and Jardim do Éden beaches showed a dissipative morphodynamic state, in the five studied days $(6.7<\Omega<8.9 / 5.7<\Omega<10.1 /$ $6.7<\Omega<8.9$, respectively), except in the fourth day, in Harmonia beach, when a stage similar to "rhythmic bar and beach" $(\Omega=4,3)$ was observed. The average beach slope was $1.3^{\circ}$ in Tramandaí, and $2^{\circ}$ in Harmonia and Jardim do Éden. The sediment was classified as fine sand in all stations within the beaches, and showed an average grain size ranging from $0.19 \mathrm{~mm}$ to $0.25 \mathrm{~mm}$.

\section{Tramandaí Beach}

Benthic macrofauna collected with extractor tube showed a total of 17 species namely, 5 polychaetes, 2 bivalves, 1 gastropod, 8 crustaceans ( 3 isopods, 3 amphipods and 1 hippid crab) and 1 species of Echinodermata (Echinoidea). A total sum of 1,431 individuals was collected, during the five days of sampling. Station \#1 showed the highest value of mean density for the organisms (Fig. 3), while station \#3 showed the highest number of species.
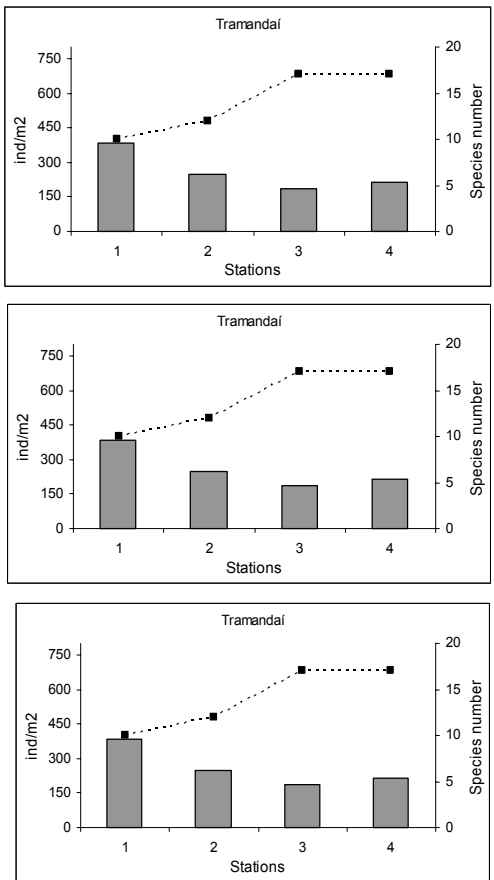

Fig. 3. Total mean density (bars) and species number per station (dotted lines) using all data set of each beach. 
Benthic macrofauna zonation in Tramandaí beach showed two distinct groups (Fig. 4; Table 1). One group was formed by station \#1, with the dominance of the isopod Excirolana armata; and another group formed by stations \#2, \#3 and \#4, represented by juveniles of bivalves Donax hanleyanus and Mesodesma mactroides, the hippid crab Emerita brasiliensis and the amphipod Puelche orensanzi (Fig. 5).

\section{Harmonia Beach}

Harmonia beach showed a total of 21 species, being5 polychaetes, 4 bivalves, 3 gastropods, 8 crustaceans (3 isopods, 3 amphipods and 2 hippid crab) and 1 species of Echinoidea. During the five days studied, the total number of individuals collected was 1,795 . Stations \#2, \#3 and \#4 showed the highest number of species (Fig. 3), while the highest density occurred in station $\# 2\left(650 \mathrm{ind} / \mathrm{m}^{2}\right)$.

Benthic macrofauna zonation showed two well defined groups (Fig. 4; Fig. 6; Table 1): one group formed by station \#1, characterized by the presence of Excirolana armata and the polychaete Euzonus furciferus, and a group involving stations \#2, \#3 and \#4, characterized by Emerita brasiliensis, Mesodesma mactroides, Donax hanleyanus and the polychaete Scolelepis gaucha.
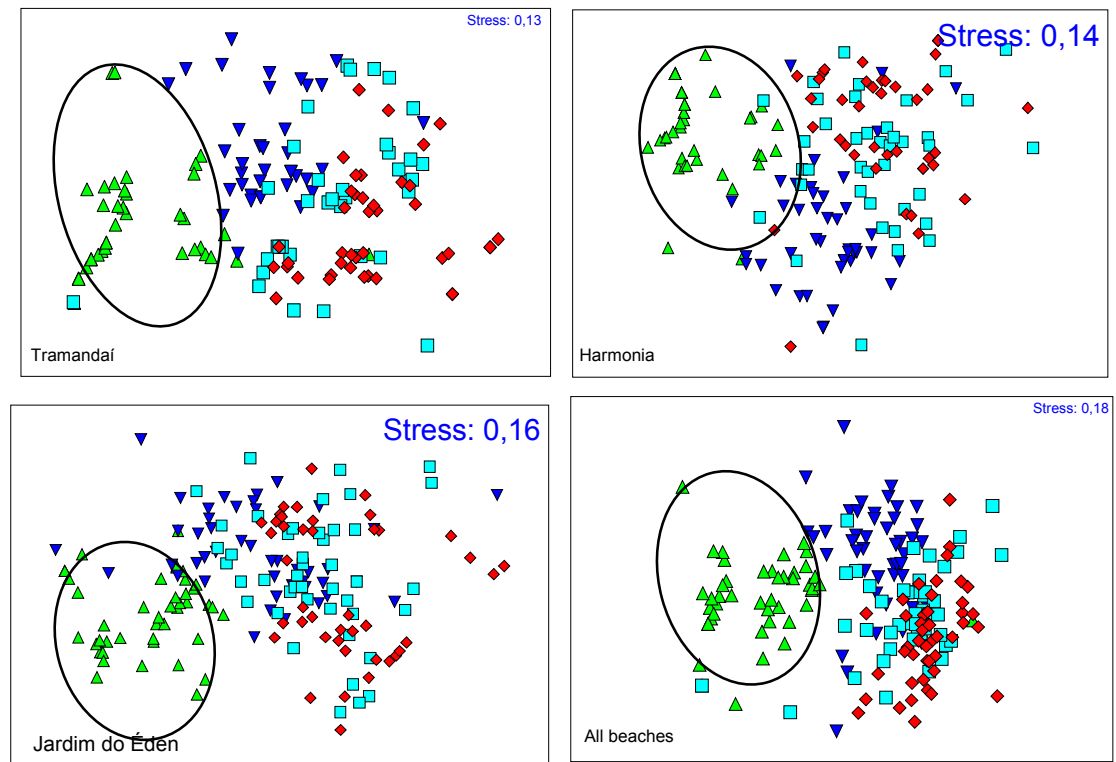

Fig. 4. MDS showing general vertical distribution of samples at Tramandaí, Harmonia and Jardim do Éden, besides the full data set of the three beaches. Triangle - station 1 (circled); triangle turned down - station 2; square - station 3 and lozenge - station 4.

Table 1. Similarity analysis (ANOSIM) using data set of Tramandaí, Harmonia and Jardim do Éden beach. Stations were used as factors. Tramandaí: global statistic $\mathrm{R}=0.491 ; \mathrm{p}=0.1 \%$. Harmonia: global statistic $\mathrm{R}=0.524 ; \mathrm{p}=0.1 \%$. Jardim do Éden: Global statistic $\mathrm{R}=0.43 ; \mathrm{p}=0.1 \%$.

\begin{tabular}{ccccccc}
\hline \hline Stations & $\mathrm{R}($ tram $)$ & $\mathrm{P}(\%)$ & $\mathrm{R}($ harm $)$ & $\mathrm{P}(\%)$ & $\mathrm{R}(\mathrm{Jard})$ & $\mathrm{P}(\%)$ \\
\hline $1-2$ & 0,723 & 0,1 & 0,749 & 0,1 & 0,576 & 0,1 \\
$1-3$ & 0,552 & 0,1 & 0,688 & 0,1 & 0,725 & 0,1 \\
$1-4$ & 0,746 & 0,1 & 0,734 & 0,1 & 0,769 & 0,1 \\
$2-3$ & 0,210 & 0,1 & 0,328 & 0,1 & 0,122 & 0,1 \\
$2-4$ & 0,428 & 0,1 & 0,462 & 0,1 & 0,219 & 0,1 \\
$3-4$ & 0,058 & 0,5 & 0,047 & 0,2 & 0,099 & 0,1 \\
\hline
\end{tabular}




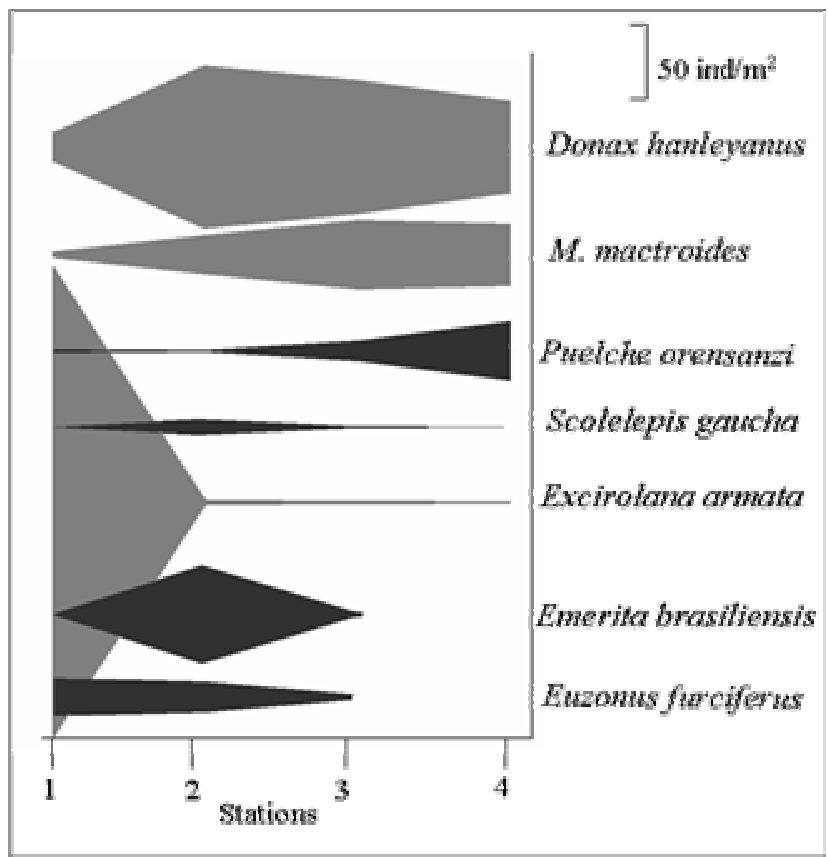

Fig. 5. Kite diagram showing general vertical distribution of most abundant species at Tramandaí beach.

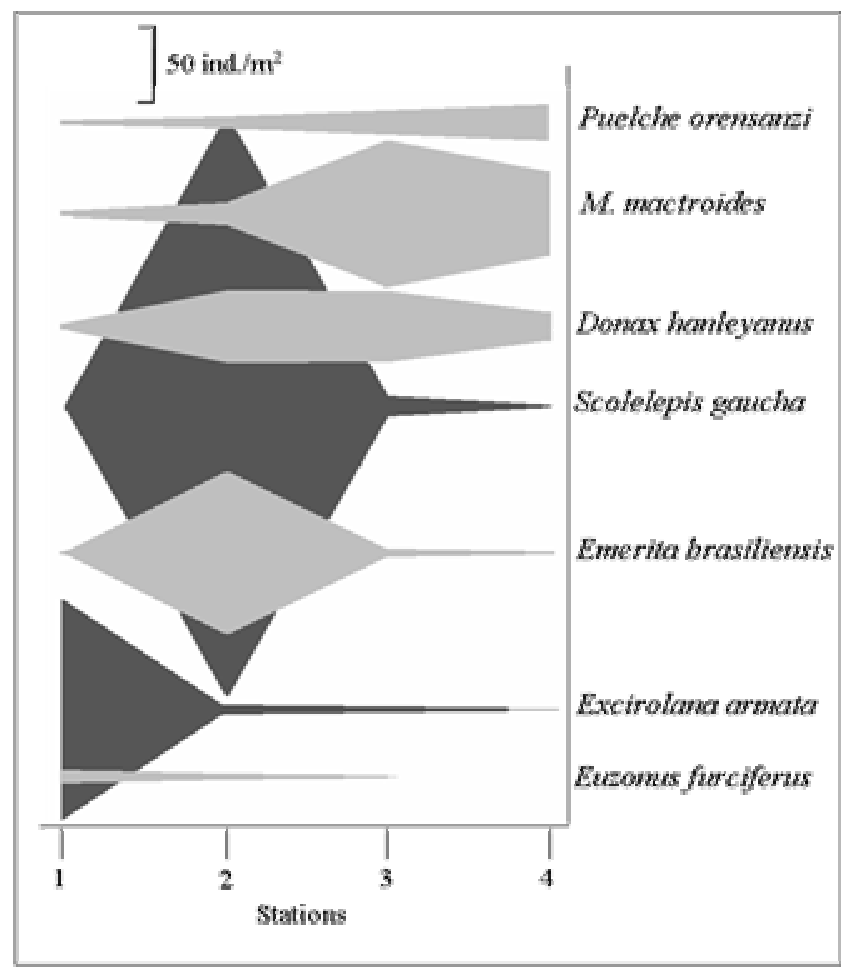

Fig. 6. Kite diagram showing general vertical distribution of most abundant species at Harmonia beach. 
Jardim do Éden Beach

Benthic macrofauna showed a total of 18 species: 4 crustaceans (2 hippid crabs and 2 isopods), 5 polychaetes, 5 molluscs $(3$ bivalves and 2 gastropods), 3 amphipods and 1 Echinodermata (Echinoidea). During the five days studied, the total number of collected individuals was 3,882. Station \#1 showed the highest mean density (about $1,300 \mathrm{ind} / \mathrm{m}^{2}$; Fig. 3), while station \#3 showed the highest number of species (17).

Jardim do Éden beach showed a general zonation pattern with stations separated into two groups (Fig. 4; Table 1). One group was formed only by station $\# 1$, characterized by the dominant presence of Excirolana armata (Fig. 7) and, in a lesser degree, by Donax hanleyanus. Another group was formed by stations \#2, \#3 and \#4, mainly characterized by the dominance of $D$. hanleyanus, in higher densities than in station \#1, Mesodesma mactroides, Emerita brasiliensis (station \#2) and Donax gemmula, mainly in station \#4.7
The Three Beaches

Through visual observations, the presence of crabs Ocypode quadrata and their burrows in the supralittoral was verified in the three studied beaches.

No significant difference was found in abundance or composition of the benthic community between sampling stations between transects within the same beach (ANOSIM; $p>0.05$ ) or between transects among the three beaches (ANOSIM; $\mathrm{p}>$ $0.05)$.

The set of data from the three beaches together showed the same pattern already described for each one individually. Stations were separated into two groups (Fig. 4; Table 2). The first one includes station $\# 1$ and the second includes stations \#2, \#3 and \#4.8.

Group 1 was dominated by Excirolana armata (90\% of contribution), while group 2 was mainly composed by Donax hanleyanus $(46 \%$ of contribution), Mesodesma mactroides (26\%), in a lesser degree, by Puelche orensanzi (7\%), Donax gemmula (5\%) and Emerita brasiliensis (4\%; Fig. 8).

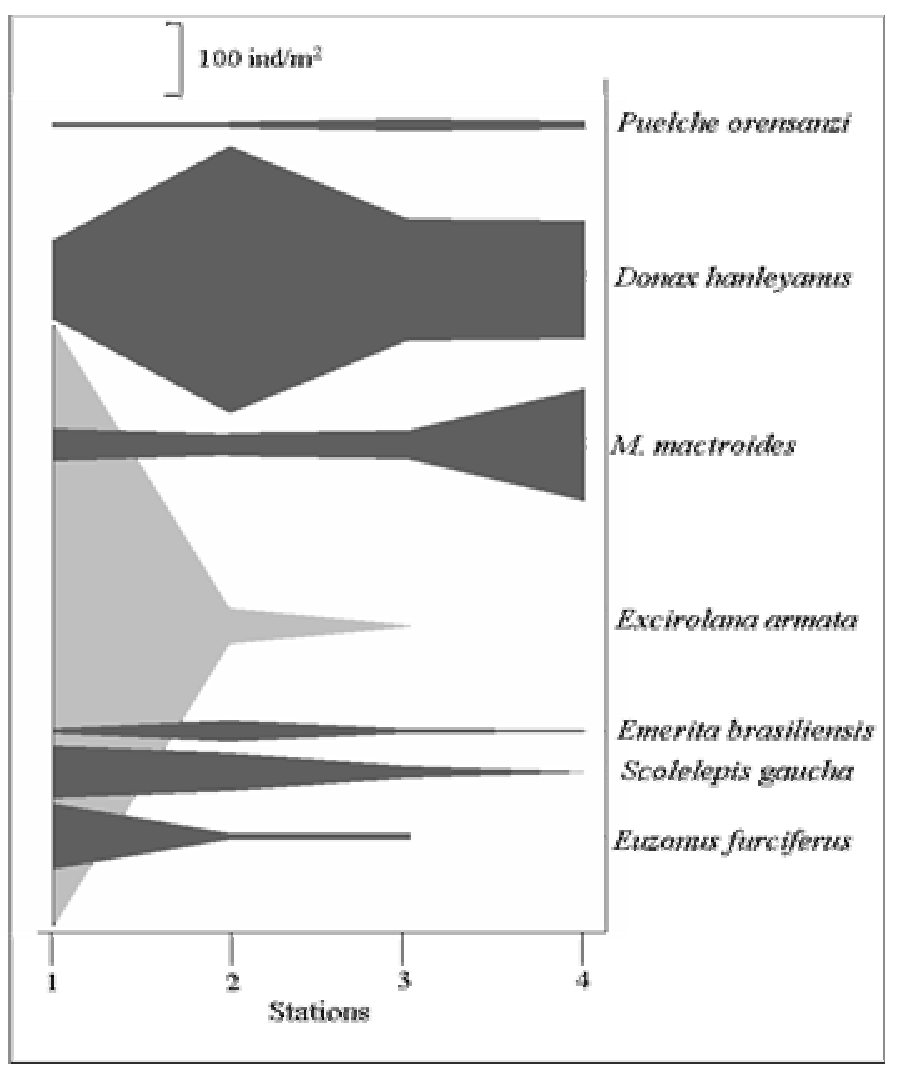

Fig. 7. Kite diagram showing general vertical distribution of most abundant species at Jardim do Éden beach. 
Table 2. Similarity analysis (ANOSIM) using all data set of the three beaches. Stations were used as factors. Global statistic $\mathrm{R}=0,515 ; \mathrm{p}=0,1 \%$.

\begin{tabular}{ccc}
\hline \hline Stations & Statistic R & $\mathrm{P}(\%)$ \\
\hline $1-2$ & 0.708 & 0.1 \\
$1-3$ & 0.743 & 0.1 \\
$1-4$ & 0.835 & 0.1 \\
$2-3$ & 0.278 & 0.1 \\
$2-4$ & 0.428 & 0.1 \\
$3-4$ & 0.032 & 1.3 \\
\hline
\end{tabular}

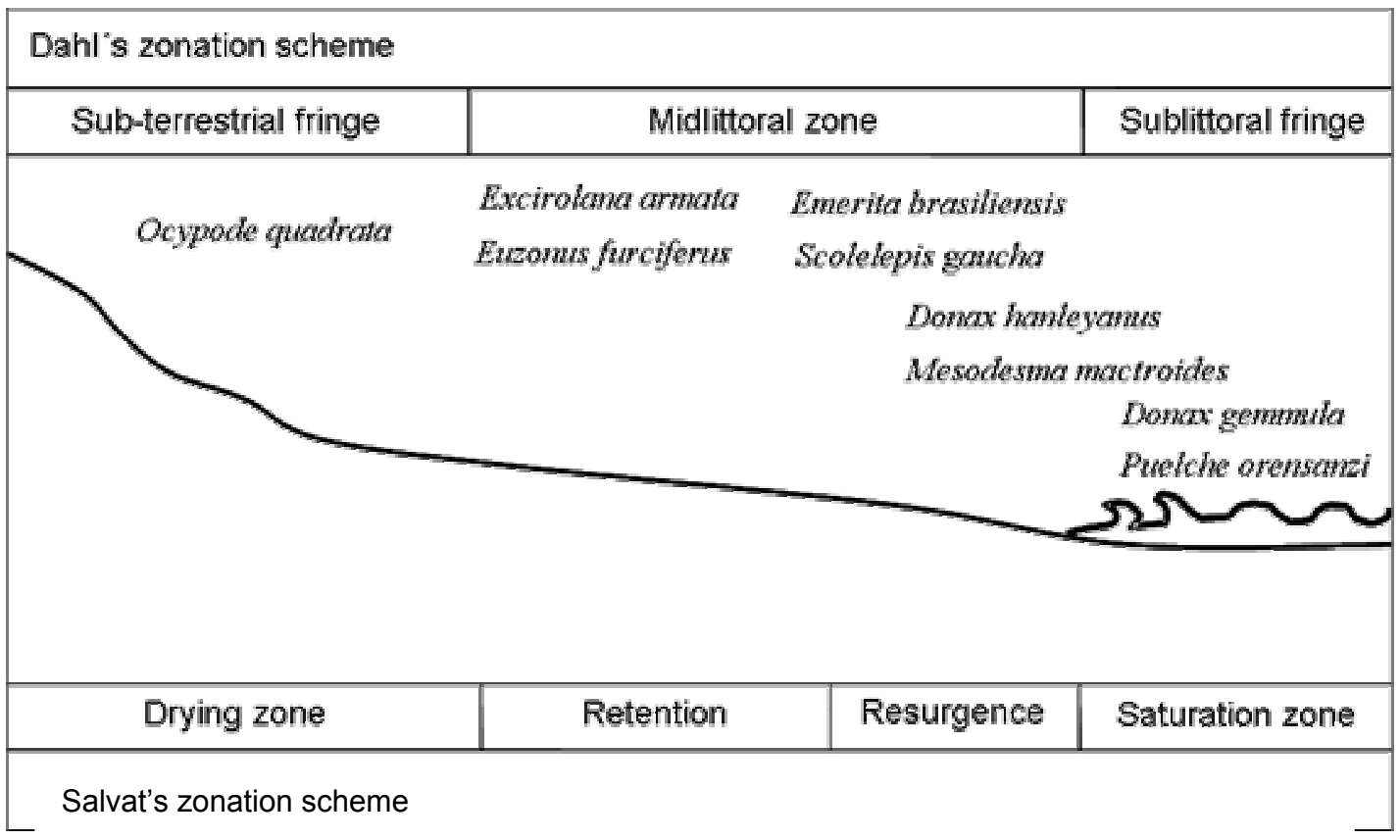

Fig. 8. Macrofauna zonation scheme of this study compared to general sandy beach schemes proposed by Dahl (1952) and Salvat (1964)

\section{Discussion}

The sampling design in this study does not allow definitive analysis of zonation. Nevertheless, some generalizations can be made. The dissipative sandy beaches of Tramandaí, Harmonia and Jardim do Éden presented a benthic zonation pattern typical of sandy beaches, and broadly similar to the biological scheme proposed by Dahl (1952). The highest zones in the beach profile presented higher temporal stability of fauna than the lower zones (low midlittoral and inner breaker zone). Benthic macrofauna showed a similar horizontal distribution in the three beaches, which presented relatively little environmental variations, especially considering sediment grain size and beach slope.

Topographic profiles showed little variation along the days. Only on the last day, in Harmonia beach, erosion was verified, possibly due to the storm surge that caused low height and short period waves. This fact was confirmed by the presence of diatom Asterionellopsis glacialis bloom, a clear indicator of storm surges in southern Brazil (Gianuca, 1983; Odebrecht et al., 2003). Sediment grain size did not show differences between sampling stations within each beach or between beaches, ranging from $0.19 \mathrm{~mm}$ to $0.25 \mathrm{~mm}$. This composition of fine sand is typical of intermediate beaches, with moderate to high waves $(0.5$ to $2.5 \mathrm{~m})$ and long period (Short, 2003). Some studies showed that species richness, density and biomass are inversely related to sediment grain size and beach slope (McLachlan \& Jaramillo, 1995; McLachlan et al., 1993; Defeo et al., 1992). On the other hand, Veloso \& Cardoso (2001) studying Rio de Janeiro beaches, showed that macrofauna abundance was not related to sediment grain size, and beach width or slope. 
The results of the present work indicated that sediment grain size did not determine the variations on the structure of the macrobenthic association on the three beaches due to its homogeneous composition within and between the studied beaches. Sediment particle size is an important factor conditioning sandy beach fauna. Larger particles are less favorable to the fauna species, permitting rapid water drainage from the sediment, while smaller particles are more favorable, as they hold water in the interstices (Little, 2000). Grain size differences may lead to distinct patterns of food concentration, which influence the patch distribution of fauna, along with beach hydrodynamic characteristics (Defeo et al., 1992). Sandy beach fauna may be very selective for sediment grain size (Brown, 1983).

Three faunistic zones appear to be discernible in the three studied beaches. The supralittoral, characterized by the presence of the ghost crab Ocypode quadrata; the midlittoral, typically inhabited by high densities of Excirolana armata and the presence of Euzonus furciferus; a sublittoral fringe inhabited by Mesodesma mactroides, Donax hanleyanus, Emerita brasiliensis and Scolelepis gaucha, the upper levels of this zone being characterized by Donax hanleyanus and E. brasiliensis, while the lower levels were dominated by D. hanleyanus and juveniles (smaller than $10 \mathrm{~mm}$ in length) of Mesodesma mactroides and Puelche orensanzi.

This result is in agreement with the universal scheme proposed by McLachlan \& Jaramillo (1995), who defined three zones based on the distribution of certain taxa: supralittoral zone, characterized by the presence of air-breathing crustaceans, such as Ocypodid crabs and other groups; littoral zone, mainly inhabited by cirolanid isopods, haustoriid and other amphipods and polychaetes such as Euzonus and Scoleleps and sublittoral zone, occupied by hippid crabs, mysids, donacid bivalves, idoteid and haustoriid amphipods, among other taxa, with the latter zone showing a tendency to subdivide into dissipative states.

Future studies should increase the number of across-shore stations at each beach in order to better understanding the dynamics of the macrofauna zones and discern more clearly whether the lowest zone can be subdivided.

The presence of the ghost crab Ocypode quadrata in the supralittoral may be related to the subterrestrial zone characterized by Dahl (1952) and the zone of dry sand by Salvat (1964).

The general zonation scheme proposed by Dahl (1952) shows that the midlittoral is the region of distribution of cirolanid isopods and includes the zones of retention and resurgence described by Salvat (1964). In the present work a strip of Excirolana armata was found in the midlittoral. This strip may be defined as the zone of retention by Salvat (1964). The third zone, low midlittoral/inner breaker zone, is characterized as the infralittoral fringe according to Dahl (1952) and a mixture of resurgence and saturation zones in Salvat's description.

Other authors (Gianuca, 1983; Jaramillo et al., 1993; Brazeiro \& Defeo, 1996) also found similar results for the zonation of sandy beaches in South America, with some peculiarities. Gianuca (1983), studying the southern shore of Rio Grande do Sul, found in the supralittoral, besides the Ocypode quadrata, the talitrid amphipod Orchestoidea brasiliensis in the lower levels of this zone, indicating that it is a transition zone between subtropical and temperate climates. In the midlittoral, besides the tidal migrators, he found Excirolana armata, in agreement to the scheme proposed by Dahl (1952), although the vertical distribution of this species reached the swash zone.

In Uruguay, Braseiro \& Defeo (1996) distinguished three faunistic zones in dissipative beaches. The supralittoral, mainly dominated by Orchestroidea brasiliensis, Excirolana brasiliensis and in a lesser degree by Euzonus furciferus; midlittoral, characterized by the abundance of Excirolana armata and a lower zone, typically inhabited by Mesodesma mactroides, Donax hanleyanus, the amphipod Phoxocephalopsis zimmeri and Emerita brasiliensis on its higher part and the isopod Macrochiridothea lilianae and the gastropods Buccinanops duartei and Olivancillaria vesica auricularia on its lower part. In the coast of Chile, Jaramillo et al. (1993) found similar results as Dahl (1952), in beaches with intermediate and dissipative characteristics.

In sandy beaches in Australia, James \& Fairweather (1996) found a division in the intertidal zone in three zones: high zone, extending up to $10 \mathrm{~m}$ above the drift line, dominated by two species of isopods; medium zone ranging from the lower limit of the high zone up to the top of the swash zone, dominated by the polychaete Hemipodus sp.; and the swash zone, with more species than both other zones, and dominated by amphipods, the polychaete Hemipodus sp., Donax deltoides and a species of cumacean. James \& Fairweather (1996) emphasized the necessity to consider both vertical and horizontal variation in order to describe the spatial pattern of distribution for assemblages and species in sandy beaches. These authors questioned the validity of studies that consider solely the vertical distribution of fauna, regardless to horizontal variation. Significant horizontal variations were found between assemblages of macrofauna with differences between the macrofauna in the supralittoral and swash zone, though, between transects within the same site, no 
differences occurred in these zones. They concluded that horizontal variation occurred in composition of assemblages and also in the relative abundance of the same species between transects and site in a beach that showed hydrodynamic variability.

Horizontal variation in the fauna was not detected in this study. The sampling stations did not show differences regarding the faunistic abundance and composition within each beach; stations at a same level showed similar characteristics in composition and abundance. This result was influenced by the similarities in the hydrodynamic characteristics, beach slope and sediment grain size found over the three beaches.

The three beaches studied here were homogeneous in faunistic composition during the period of sampling. Environmental characteristics of these beaches were similar with little variation in slope or sediment grain size, and this contributed to the similarity in the composition of benthic assemblage. Our conclusion is that the surveyed beaches showed relative homogeneity regarding environmental characteristics, species composition and horizontal distribution of benthic macrofauna.

\section{AcKNOwledgments}

The authors thank the technician Nilton Araújo, for the help in species sorting and identification, the post-grad students Leonir André Colling and Pedro Pereira, for helping in field work and Dr. Cristiane Serejo, from Museu Nacional/RJ, for the identification of the species of Amphipoda. FMN also thanks the Conselho Nacional de Pesquisa $(\mathrm{CNPq})$, for the support with a student grant.

\section{REFERENCES}

Birkemeier, W. A. 1985. Fast, accurate two person beach surveys. Coast. Engng. Tech. Aid, $81,17 \mathrm{p}$.

Borzone, C. A. \& Gianuca, N. M. 1990. A zonação infralitoral em praias arenosas expostas. In: Simpósio sobre Ecossistemas da Costa Sul e Sudeste Brasileira. II. Águas de Lindóia, 1990. Anais. São Paulo, ACIESP, 3:280-296

Borzone, C. A. \& Souza, J. R. B. 1997. Estrutura da macrofauna bentônica no supra, meso e infralitoral de uma praia arenosa do sul do Brasil. Oecol. Bras., 3:197212

Borzone, C. A.; Souza, J. R. B. \& Soares, A. G. 1996. Morphodynamic influence on the structure of inter and subtidal macrofaunal communities of subtropical sandy beaches. Revta. chil. Hist. Nat.., 69:565-577.

Brazeiro, A. \& Defeo, O. 1996. Macroinfauna zonation in macrotidal sandy beaches: is it possible to identify patterns in such variable environments? Estuar. coast. Shelf Sci., 42:523-536.
Brown, A. C. 1983. The ecophysiology of sandy beach animals. In: McLachlan, A. \& Erasmus, T., eds. Sandy beaches as ecosystems. Boston, Dr. W. Junk. p. 575-605.

Dahl, E. 1952. Some aspects of the ecology and zonation of the fauna of sandy beaches, Oikos, 4: 1-27.

Defeo, O.; Jaramillo, A. \& Lyonnet, A. 1992. Community structure and intertidal zonation of the macroinfauna on the Atlantic coasts of Uruguay. J. coast. Res., 8:830-839.

Dexter, D. M. 1992. Sandy beach community structure: the role of exposure and latitude. J. Biogeogr., 19:59-66.

Gianuca, N. M. 1983. A preliminary account of the ecology of sandy beaches in southern Brazil. In: McLachlan, A. \& Erasmus, T. eds. Sandy beaches as ecosystems. Boston, Dr. W. Junk, p. 413-420.

Gianuca, N. M. 1987. Zonação e produção nas praias arenosas do litoral sul e sudeste do Brasil. In: Simpósio de Ecossistemas da Costa Sul e Sudeste Brasileira síntese dos conhecimentos. Cananéia, 1990. São Paulo, ACIESP, 1(1):313-332.

James, R. J. \& Fairweather, P. G. 1996. Spatial variation of intertidal macrofauna on a sandy ocean beach in Australia. Estuar. coast. Shelf Sci., 43:81-107.

Jaramillo, E.; Mclachlan, A. \& Coetzee, P. 1993. Intertidal zonation patterns of macroinfauna over a range of exposed sandy beaches in south-central Chile. Mar. Ecol. Prog. Ser., 101:105-118.

Little, C. 2000. The biology of soft shores and stuaries. New York. Oxford University Press, 252p.

McLachlan, A. 1990. Dissipative beaches and macrofaunal communities on exposed intertidal sands. J. coast. Res., 6:57-71.

McLachlan, A. 1996. Phisical factors in benthic ecology: effects of changing sand particle size on beach fauna. Mar. Ecol. Prog. Ser., 131: 205-211.

McLachlan, A. \& Hesp, P. 1984. Faunal response to morphology and water circulation of a sandy beach with cusps. Mar. Ecol. Prog. Ser., 19:133-144.

McLachlan, A. \& Jaramillo, E. 1995. Zonation on sandy beaches. Oceanogr. Mar. Biol. a. Rev., 33:305-335.

McLachlan, A.; Jaramillo, E.; Donn, T. E. \& Wessels, E. 1993. Sandy beach macrofauna communities and their control by the physical environment: a geographical comparison. J. coast. Res., 15(Special Issue):27-38.

Odebrecht, C.; Abreu, P. C.; Fugita, C. C. \& Bergesch, M. 2003. The impact of mud deposition on the long term variability of the surf-zone diatom Asterionellopsis glacialis (Castracane) round at Cassino beach, Brazil. J. coast. Res., 35(Special Issue):486-491.

Raffaelli, D. G.; Karakassis, I. \& Galloway, A. 1991. Zonation schemes on sandy shores: a multivariate approach. J. Exp. Mar. Biol. Ecol., 148:241-253.

Salvat, B. 1964. Les conditions hydrodinamicques interstitielles des sedimentes meubles intertidaus et la repartition verticale de la faune endogée. Cah.. Rech. Sci, Paris, 259:1576-1579.

Short, A. D. 2003. Australian beach systems - The morphodynamics of wave through tide-dominated beachdune systems. J. coast. Res., 35(Special Issue):7-20.

Souza, J. R. B. \& Gianuca, N. M. 1995. Zonation and seasonal variation of the intertidal macrofauna on a sandy beach of Paraná State, Brazil. Sci. Mar., Barcelona, 59(2):103-111.

Suguio, K. 1973. Introdução à sedimentologia. São Paulo, EDUSP. $317 \mathrm{p}$. 
Veloso, V. G. \& Cardoso, R. S. 2001. Effects of morphodynamics on the spatial and temporal variation of macrofauna on three sandy beaches, Rio de Janeiro State, Brazil. J. mar. biol. Ass., UK Mar, 81:369-375.

Wright, L. D. \& Short, A. D. 1984. Morphodynamic variability of surf zones and beaches: a synthesis. Mar. Geol., 48:259-284.

Sources of Unpublished Material

Borzone, C. A. 1991. Ecologia de los moluscos del infralitoral raso de una playa arenosa expuesta del sur del Brasil. Tese de Doutorado, Universidade de Buenos Aires. 221p.

Gianuca, N. M. 1985. The ecology of a sandy beach in southern Brazil. PhD Thesis. University of Southampton, $330 \mathrm{p}$.

(Manuscript received 17 October 2005; revised 16 January 2006; accepted 25 March 2006) 